УдК 349.2

B. В. Волинець

\title{
ЄВРОПЕЙСЬКИЙ ДОСВІД ПРАВОВОГО РЕГУЛЮВАННЯ ОРГАНІЗАЦІЙНО-УПРАВЛІНСЬКИХ ВІДНОСИН У ТРУДОВОМУ ПРАВІ
}

Актуальність теми. Однією з сучасних тенденцій розвитку трудових і пов'язаних із ними правовідносин в Україні є розвиток соціального партнерства і колективно-договірного регулювання. Проте, незважаючи на наявний вітчизняний досвід у цій сфері, можна стверджувати про недостатнє використання потенційних можливостей запровадження та функціонування цих інститутів трудового права, що обумовлює необхідність запозичення позитивного європейського досвіду, урахування європейських норм і стандартів у контексті інтеграції України до Європейського Союзу та запланованого прийняття Трудового кодексу України. Особливої уваги потребує вдосконалення правового регулювання організаційно-управлінських відносин у трудовому праві як основи формування політики соціального партнерства в державі.

Стан наукового дослідження. Вивченню цієї проблематики присвячені наукові праці багатьох вітчизняних і зарубіжних учених, таких як Н.Б. Болотіна, О.М. Василенко, В.С. Венедиктов, Н.Д. Гетьманцева, Ю.П. Дмитренко, О.В. Жадан, В.В. Жернаков, С.І. Запара, 3.Я. Козак, I.О. Лосиця, П.Д. Пилипенко, Г.І. Чанишева, О.М. Ярошенко та ін. Однак правове регулювання організаційно-управлінських відносин у трудовому праві та європейський досвід його здійснення висвітлені фрагментарно, що актуалізує обраний напрям дослідження.

Отже, метою статті є дослідження європейського досвіду правового регулювання організаційно-управлінських відносин у трудовому праві.

Виклад основного матеріалу. Не викликає сумнівів, що розвинені країни Європи є родоначальниками розвитку нормативно-правового регулювання як власне трудових, так і організаційно-управлінських відносин у трудовому праві.

Як слушно відзначає В.П. Зайцев із цього приводу, у країнах Західної Європи правове регулювання організаційно-управлінських відносин було 
започатковане в другій половині XVIII - на початку XIX ст. як захисна реакція найманих працівників на соціальні та політичні наслідки промислового перевороту, що зруйнував традиційні відносини між роботодавцями та працівниками [1, с. 90].

Суб'єктивне право на участь в управлінні виробництвом і встановленні умов праці є складовою частиною правового статусу трудящих і профспілкових органів, відзначає О.В. Смирнов [2, с. 40]. Вперше його передбачила ст. 165 Конституції Німеччини від 11.08.1919 р., відповідно до якої робітники та службовці мали право разом із підприємцями на рівних умовах брати участь у регулюванні заробітної плати та умов праці, а також у загальному господарському розвитку продуктивних сил [3, с. 239]. Далі, на початку XX ст., у багатьох європейських державах колективно-договірна система набула офіційного статусу та стала відігравати ключову роль у регулюванні відносин у сфері праці. Цей процес був започаткований датським Цивільним кодексом 1907 р. та швейцарським Кодексом обов'язків 1911 р. Згодом законодавче регулювання названих відносин відбулося в Норвегіі (1915 р.), Німеччині (1918 р.), Франції (1919 р.) та Нідерландах (1927 p.).

Звертаючись до аналізу законодавства Європейського Союзу з приводу врегулювання організаційних та управлінських відносин, необхідно зазначити таке. Як відзначає Р. Бонвичини, основу для побудови системи соціального партнерства в ЄС становлять статті 5 і 6 Європейської соціальної хартії 1989 р. (переглянутої 03.05.1996 р.), у яких закріплюється право на об’єднання й на ведення колективних переговорів» [4, с. 116-117]. Дещо іншої точки зору дотримується B.I. Муравйов, який вважає, що правовою базою розвитку соціального діалогу в рамках $Є \mathrm{C} \in$ статті $151-156$ розділу X «Соціальна політика» Договору про функціонування Європейського Союзу (далі - ДФЄС), у якому соціальний діалог визначено серед спільних цілей, які ставлять перед собою Союз та держави-члени (ст. 151 ДФЕС) [5].

Базові правила щодо права на об’єднання містяться у регіональних угодах - Європейській конвенції про захист прав людини і основних свобод, Європейській соціальній хартії, Хартії Співтовариства про основні соціальні права трудящих. Хартія Співтовариства про основні соціальні права трудящих від 09.12.1989 р. містить положення щодо профспілкових прав суб'єктів трудових правовідносин (ст. ст. 11-14). У ч. 2 ст. 11 визначається, що кожний роботодавець і кожний працівник мають свободу вступати або не вступати в подібні організації, не зазнаючи внаслідок цього будьяких персональних або професійних збитків [6].

У сфері соціального партнерства можна виокремити такі директиви $Є С$ : Директива 94/45/ЄС Ради від 22.09.1994 р. «Про заснування на підприємствах і групах підприємств, що діють у масштабах Співтовариства, Європейського комітету підприємства або процедури з метою інформування працівників і проведення з ними консультацій»; Директива 2001/86/ ЄС Ради від 08.10.2001 р. «Про доповнення статусу європейського акціонерного товариства правилами, що регулюють залучення працівників до управ- 
ління»; Директива 2003/72/ ЄС Ради від 22.07.2003 р. «Про доповнення статусу європейського кооперативного суспільства правилами, що регулюють залучення працівників до управління».

Як справедливо зазначає А.О. Четвериков, європейська інтеграція, нормативні та інші акти, ухвалені органами влади Союзу, звернені зрештою не до держав, а безпосередньо до людини. Тією чи іншою мірою вони зачіпають повсякденні інтереси всіх громадян [7, с. 47]. Так, наприклад, Директива Ради європейських співтовариств від 14.10.1991р. «Про обов'язок роботодавця інформувати своїх службовців про умови, що застосовуються до трудового договору чи трудових відносин» (91/533/ЄЕС) зобов'язує роботодавця інформувати своїх службовців про суттєві умови, що застосовуються до трудового договору чи трудових відносин.

До суттєвих умов належать особистості сторін; місце роботи (там, де немає фіксованого чи основного місця роботи, - принцип, за яким працівник працевлаштований на різні місця, та зареєстроване місце розташування підприємства, або, якщо доречно, постійне місце проживання роботодавця); посада, ступінь, характер або категорія роботи, на яку влаштований працівник; коротка характеристика або опис роботи; дата початку трудового договору чи трудових відносин; тривалість оплачуваної відпустки, що має надаватися працівнику, чи, якщо вона не може бути визначена під час надання такої інформації, процедури розподілення та визначення такої відпустки; терміни повідомлення, яких мають дотримуватись роботодавець та працівник, якщо їх трудовий договір чи трудові відносини припиняються, або, якщо це не може бути визначено під час надання інформації, метод визначення таких термінів повідомлення; початковий основний рівень, інші складові елементи та частота оплати праці, які призначені працівнику; довжина звичайного робочого дня і тижня працівника; колективні трудові угоди, що визначають умови роботи працівника (або у випадку колективних трудових угод, що укладені за межами підприємства спеціальними об'єднаними органами чи установами, назва компетентного органу чи об'єднаної установи, у яких угоди були укладені) [8].

Варто зазначити, що державами - членами ЄC 07.02.1992 р. було підписано Угоду про соціальну політику, яка фактично є правовою основою функціонування «соціальної спільноти» в Європі. Цією угодою встановлюється, що держави-члени можуть за низкою аспектів трудового права приймати рішення не консенсусом, а кваліфікованою більшістю.

Деякі західні науковці, зокрема В. Бломайєр, аналізуючи сучасний стан розвитку трудового права, який здійснюється на рівні $€$ С, зазначає, що існують проблеми європейського законодавства у сфері колективного трудового права через те, що в державах-членах сформувались усілякі організації й традиції, які на європейському рівні ледь можна привести до єдності. Спільність, на думку автора, полягає лише в тому, що в усіх країнах існують профспілки й об'єднання роботодавців [9, с. 454].

Варто погодитися і з В.I. Муравйовим, який робить висновок, що законодавство ЄС впроваджує мінімальні стандарти залучення працівників до 
управління підприємством, але регулювання цього питання відбувається переважно на національному рівні держав-членів. У більшості держав ЄС існують системи непрямої та представницької участі працівників в управлінні, які функціонують на основі законодавства та колективних угод (Австрія, Бельгія, Данія, Італія, Нідерланди, Німеччина, Фінляндія, Франція тощо). Робочі ради в Німеччині, окрім права на інформування та консультації, мають право на прийняття спільних рішень 3 питань щодо фінансового, економічного стану підприємства, зайнятості та питань, пов'язаних $з$ управлінням персоналом. У Франції розширено зміст права на інформування та консультації. Робочі ради мають майже однакові права з аудиторами компанії щодо доступу до необхідної інформації. Найширші можливості обмеження адміністрації підприємства щодо прийняття фінансових та економічних рішень мають робочі ради у Швеції та Фінляндії. Рішення, прийняті без проведення переговорів 3 представниками профспілок, можуть бути забороненими до виконання [5].

Законодавство Данії, Фінляндії та Швеції $є$ поєднанням законодавства і колективних угод. Причому законодавство встановлює певні рамки, правила. Колективні угоди же ї уточнюють, розширюють і деталізують. Закон про працю Хорватії від 04.12.2009 р. містить ст. 7 під назвою «Свобода договору», яка дозволяє сторонам встановлювати умови праці, що покращують умови, встановлені законом [10]. Ст. 231 Трудового кодексу Словаччини закріплює, що колективні угоди регулюють умови праці, включаючи умову про заробітну плату, відносини між працівником і роботодавцем тощо [11]. У Трудовому кодексі Франції, відзначає Г.В. Шонія, міститься окремий розділ «Колективні угоди». Він визначає правила, за допомогою яких реалізується право робітників на колективні переговори щодо умов найму та праці. Укладати колективний договір мають право профспілки, визнані представницькими, з одного боку, та організації роботодавців або окремі роботодавці - з другого. Колективний договір може містити кращі положення, ніж ті, що передбачені чинним законодавством. Для всіх підприємств із загальною кількістю понад 50 працівників закон вводить обов'язкові щорічні колективні переговори з трьох питань: заробітна плата, зайнятість і тривалість робочого дня [12, с. 12].

У Швеціі, відзначає А.М. Волков, основною функцією колективного договору вважається збереження трудового миру. У разі його відсутності дозволяються страйки і локаути. Інша важлива його функція - регулювання заробітної плати та умов праці. У зв'язку з опосередкованим впливом держави на відносини у сфері праці через систему оподаткування та соціально-економічні заходи, на практиці профспілки та організації роботодавців досить часто консультуються з урядом щодо регулювання трудових відносин. Ключовими шведськими законами, що захищають права працівників, є Закон «Про трудові спори» 1974 р. і Закон «Про захист праці» (1982 р.) [13, с. 48].

На нашу думку, особливістю організаційно-управлінських відносин у трудовому праві Швеції є також обов’язок сторін соціального партнерства 
укладати колективний договір на визначений строк, як правило 2-3 роки, після закінчення строку якого сторони зобов'язуються вступити в переговори щодо укладення нової угоди. На відміну від Швеції, в Україні згідно зі ст. 9 Закону України «Про колективні договори та угоди» колективний договір, угода продовжує діяти до того часу, поки сторони не укладуть новий або не переглянуть чинний, якщо інше не передбачено договором, угодою [14]. Тому вважаємо доцільним законодавчо встановити максимальний термін дії колективного договору - 3 роки, зважаючи на позитивні наслідки такої нормативно-правової новели, що вбачаємо передусім у стимулюванні фактичного колективного вирішення питань і соціального діалогу, врахуванні сучасного соціально-економічного стану в показниках оплати праці тощо.

Заслуговує на увагу також досвід правового регулювання у сфері виробничої демократії в соціалістичних країнах. Зокрема, за Кодексом про працю Угорської Народної Республіки 1967 р. права трудящих у цій сфері розділялися на дві великі групи. До першої належали права, пов'язані зі встановленням умов праці та культурно-побутовим обслуговуванням працівників. До другої групи належали права, направлені на забезпечення участі трудящих в управлінні підприємством, у прийнятті рішень на рівні підприємства (участь у роботі виробничих нарад тощо). Під час кодифікації законодавства про працю соціалістичних країн участь трудящих в управлінні виробництвом отримала широку правову основу. В Угорщині склався правовий інститут заводської демократії - система норм, що була направлена на забезпечення участі трудящих в управлінні підприємствами. А в Польській Народній Республіці 20.12.1958 р. було ухвалено Закон про робітниче самоуправління [15, с. 31-32, 121, 208].

Досліджуючи досвід організації праці в Австрії, В.А. Туманов відзначає, що згідно із Законом «Про колективні трудові договори» 1974 р. виробнича рада укладає з підприємцем угоду, у якій визначається широке коло виробничих, економічних і соціальних питань. В угоді стосовно найманих працівників зазначаються заходи усунення або пом'якшення шкідливих наслідків змін, які відбулися в процесі виробничої діяльності. Угода передбачає заходи для запобігання нещасним випадкам, професійним захворюванням, створення належних умов праці, використання відпустки, тимчасове зменшення або збільшення тривалості робочого часу, виплат, а також надання виплат, порядок участі в розподілі прибутку, виплати пенсій із фонду підприємств $[16$, с. 291$]$.

Оремо варто зупинитися на одному з головних, на нашу думку, питань колективного договору чи угоди - організації оплати праці. Договірне регулювання оплати праці здійснюється системою колективних угод.

У країнах Західної Європи національні та секторальні угоди передбачають:

1) мінімальну зарплату у масштабах країни або за секторами економіки;

2) загальний порядок індексації зарплати.

На рівні галузевих угод: 
1) мінімальні тарифні ставки в основних професійно-кваліфікаційних групах;

2) форми та системи зарплати;

3) надбавки та доплати;

4) механізм індексації зарплати;

5) розміри соціальних виплат і пільг.

На рівні підприємств, фірм і компаній:

1) тарифні ставки;

2) розміри надбавок і доплат;

3) порядок індексаціі;

4) системи участі у прибутках та акціонерному капіталі;

5) розміри соціальних виплат і пільг [17, с. 44].

Галузеві колективні договори, які дуже поширені в Італії, Франції та ФРН, охоплюють від двох-трьох до декількох десятків галузей і мають дуже загальний характер. Ці договори встановлюють мінімальну заробітну плату в основних професійно-кваліфікаційних групах працівників, гарантовані розміри надбавок за стаж, надурочну та складну роботу, преміальні системи, умови індексації заробітної плати, порядок надання та розміри соціальних виплат і пільг групам працівників [18, с. 81].

У Німеччині відповідно до принципу «тарифної автономії соціальні партнери самостійно домовляються про умови і оплату праці, але з урахуванням вимог чинного трудового законодавства. На рівні галузі в ході укладання колдоговору з питань заробітної плати порушуються перш за все питання мінімальної заробітної плати і тарифних сіток, а на рівні договорів підприємств більшою мірою конкретизуються форми підвищення заробітної плати, іiі розмір і періодичність [19, с. 87]. Договірне визначення обсягів заробітної плати та інших матеріальних пільг залишається головною темою колективних переговорів та угод між соціальними партнерами на рівні підприємства (фірми, компанії), галузі, регіону і держави, включаючи тристоронні угоди. У країнах Центральної та Східної Європи центральне місце в колективних договорах займають два питання: заробітна плата і гарантії зайнятості.

Висновок. Таким чином, можна відзначити, що дослідження європейського досвіду регулювання організаційно-управлінських відносин у трудовому праві свідчить про те, що однією з головних тенденцій є практика фактичної участі трудового колективу в управлінні підприємством, направлена на вирішення питань соціального й економічного розвитку трудового колективу підприємства та роботодавця, що здебільшого врегульовується шляхом ведення переговорів між зазначеними суб'єктами. Позитивним для України вважаємо передусім мирний метод соціального діалогу між суб'єктами трудових правовідносин у вирішенні трудових конфліктів, що виникають у межах організаційно-управлінських відносин у трудовому праві.

Також, як було зазначено нами вище, пропонуємо передбачити максимальний термін укладання колективного договору, угоди -3 роки, який 
треба закріпити в ст. 9 Закону України «Про колективні договори та угоди» з метою підвищення ролі суб'єктів соціального партнерства та забезпечення можливості своєчасного врахування й адаптації до змін соціально-економічного та політико-правового становища в державі тощо.

\section{Література}

1. Зайцев В.П. На переднем крае борьбы с капиталом. Движение шоп-стюардов в Англии: история и современность / В.П. Зайцев. - М. : Мысль, 1988. - 205 с.

2. Смирнов О.В. Трудовое право социалистических стран / О.В. Смирнов, А. Вельтнер, К.П. Уржинский и др. ; отв. ред. О.В. Смирнов. - М. : Юрид. лит., 1981. - 271 с.

3. Каскель В. Новое трудовое право / В. Каскель ; под. ред. проф. Е.А. Даниловой / пер. с нем. А. Зак. - М. : Изд-во «Вопросы труда», 1925. - 416 с.

4. Бонвичини Р. Социальное партнерство и трудовые отношения в Европе. Приемлемы ли для России европейские модели? / Р. Бонвичини. - М. : Права человека, 2005. - 336 с.

5. Право Європейського Союзу / [В.І. Муравйов та ін.] ; за ред. В.І. Муравйова; МОНУ. K. : Юрінком Інтер, 2011. - 703 с.

6. Хартія Співтовариства про основні соціальні права працівників : Міжнародний документ від 09.12.1989. - [Електронний ресурс]. - Режим доступу : http://zakon2.rada.gov.ua/laws/ show / 994_044.

7. Право Европейского Союза : [учеб. для вузов] / под ред. С.Ю. Кашкина. - М. : Юрист, 2002. - 925 с

8. Директива Ради Європейських співтовариств від 14.10.1991 р. «Про обов'язок роботодавця інформувати своїх службовців про умови, що застосовуються до трудового договору чи трудових відносин» $(91 / 533$ / ЄEC) // Official Journal L 288. - 1991. - P. 32-35.

9. Бломайер В. Европейское трудовое право / В. Бломайер / / Отдельные проблемы хозяйственного права Германии и Австрии : сб. докладов на семинаре, проведенном в рамках Темпус-проекта (г. Минск, 28 августа - 3 сентября 2000 г.). - Минск, 2001. - С. 433-459.

10. Labour Act of 4 December 2009 (Text №. 3635) // Narodne novine. - 2009-12-15. № 149. - P. 2-52.

11. Act No. 262/2006, The Labour Code. (Zakonik prace) Sbirka zakonu. - 2006-06-07. Castka 84. - P. 3146-3241.

12. Шония Г.В. Общая характеристика трудового права Франции : автореф. дис. ... канд. юрид. наук : спец. 12.00.05 / Г.В. Шония. - М., 2009. - 30 с.

13. Волков А.М. Швеция: Социально-экономическая модель / А.М. Волков. - М. : Мысль, 1991. - 188 c.

14. Про колективні договори та угоди : Закон України від 01.07.1993 р. № 3356-XII // Відомості Верховної Ради України. - 1993. - № 36. - Ст. 361.

15. Кодификация законодательства о труде социалистических стран. - М., Наука, 1979. 413 c.

16. Австрийская республика. Конституция и законодательные акты / сост. В.А. Туманов. M. : Прогресс, 1985. - 429 с.

17. Современные тенденции в регулировании коллективных трудовых отношений в мире / / Труд за рубежом. - 2000. - № 2. - С. 17-102.

18. Рочко А.В. Колдоговорная практика во Франции в 90-х годах / А.В. Рочко / / Труд за рубежом. - 1994. - № 2 (22). - С. 82-90.

19. Соболевская А.А. Функции и параметры заработной платы в рыночной экономике / А.А. Соболевская / / Труд за рубежом. - 2001. - № 3 (51). - С. 70-89. 


\section{А но т а ці я}

Волинець В. В. Європейський досвід правового регулювання організаційно-управлінських відносин у трудовому праві. - Стаття.

У статті обгрунтовується актуальність вивчення та запозичення позитивного європейського досвіду організації інститутів соціального партнерства та колективно-договірного регулювання. Особлива увага звертається на досвід правового регулювання організаційно-управлінських відносин у трудовому праві. Досліджені законодавча база й особливості правового регулювання організаційно-управлінських відносин у трудовому праві в провідних європейських країнах.

Ключові слова: трудове право, соціальне партнерство, організаційно-управлінські відносини, колективний договір, колективні переговори, правове регулювання.

\section{Анн о т а ция}

Волынец В. В. Европейский опыт правового регулирования организационно-управленческих отношений в трудовом праве. - Статья.

В статье обосновывается актуальность изучения и заимствования положительного европейского опыта организации институтов социального партнерства и коллективно-договорного регулирования. Особое внимание обращается на опыт правового регулирования организационно-управленческих отношений в трудовом праве. Исследованы законодательная база и особенности правового регулирования организационно-управленческих отношений в трудовом праве в ведущих европейских странах.

Ключевые слова: трудовое право, социальное партнерство, организационно-управленческие отношения, коллективный договор, коллективные переговоры, правовое регулирование.

\section{S u m m a r y}

Volynez $V . V$. The European experience of legal regulation of organizational and managerial relations in the labor law. - Article.

The article explains the relevance of the study and drawing the positive European experience in the organization of institutions of social partnership and collective bargaining regulations. Particular attention is noticed to the experience of legal regulation of organizational and managerial relations in the labor law. The legal framework and the peculiarities of the legal regulation of organizational and managerial relations in the labor law in the leading European countries are investigated.

Key words: labor law, social partnership, organizational and managerial relations, collective agreement, collective bargaining, legal regulation. 